To cite: A Shaw 'From disgust to dignity: Criminalisation of same-sex conduct as a dignity taking and the human rights pathways to achieve dignity restoration' (2018) 18 African Human Rights Law Journal 684-705

http://dx.doi.org/10.17159/1996-2096/2018/v18n2a12

\title{
From disgust to dignity: \\ Criminalisation of same-sex conduct as a dignity taking and the human rights pathways to achieve dignity restoration
}

\author{
Ari Shaw* \\ Independent scholar
}

\section{Summary}

Despite global advances in the rights of sexual and gender minorities, more than 70 countries worldwide still criminalise consensual same-sex conduct. Taking the case of Kenya, this article employs the concept of 'dignity takings' to underscore the direct and indirect costs of criminalising homosexuality. Criminalisation leads to a direct taking where it engenders forced examinations and medical tests, and indirect takings where the institutionalisation of stigma - labelling sexual and gender minorities as criminal - creates an environment that legitimises the use of violence against individuals on the basis of their real or perceived sexual orientation or gender identity. Viewing criminalisation as a dignity taking not only helps one to understand the direct effects by which the state is empowered to violate the bodies of lesbian, gay, bisexual and transgender persons, but also the more pernicious ways in which the state uses homophobia as a political weapon that can exclude individuals from meaningfully participating as citizens in the body politic. The article also examines the efforts of Kenyan LGBT activists to reclaim dignity by employing international human rights norms and institutions of the African regional human rights system. I argue that the pursuit of public, grassroots activism is an assertion of agency in the face of institutionalised

BA (Harvard) MSc (London School of Economics) PhD (Northwestern); amshaw@gmail.com. For helpful comments, I am grateful to John Acevedo, Adam Romero, Alexander Boni-Saenz, Bernadette Atuahene, Mneesha Gellman and Neela Ghoshal. Fieldwork in Nairobi, Kenya, during 2013 and 2014 was generously supported by the Equality, Development, and Globalisation Studies (EDGS) programme at the Buffett Institute for Global Studies, Northwestern University, and the Sexuality Programme, Northwestern University (SPAN). 
stigma and systemic violence, and that the strategic mobilisation of human rights norms has allowed activists to reframe LBGT rights in terms of fundamental rights to life and dignity guaranteed to all Africans, effectively countering the false claim that homosexuality is 'un-African'.

Key words: dignity restoration; criminalisation; same-sex conduct; forced anal examination; $L G B T$

\section{Introduction}

On 18 February 2015 two men were arrested near Mombasa, Kenya on suspicion of engaging in homosexual acts. The men were brought to the police station in Diani, a small town on Kenya's southeastern coast, where they were charged with committing an 'unnatural offence'. ${ }^{1}$ They were subsequently taken to a local hospital, where each was subjected to a forced examination of his anus, and blood samples were taken to test for HIV and hepatitis B. In the hospital the men were told to undress in full view of police and medical personnel, to lie on a table, and to place their legs in stirrups, while a physician inspected their anal orifices for signs of penetration. ${ }^{2}$ With the support of the National Gay and Lesbian Human Rights Commission (NGLHRC), a Kenyan advocacy group, the men challenged the legality of forced medical examinations and testing, arguing that it amounted to cruel and degrading treatment in violation of the Kenyan Constitution and international law. ${ }^{3}$ In June 2016, however, the Kenyan High Court at Mombasa upheld the constitutionality of such procedures, accepting the government's contention that the examinations were reasonable and in accordance with the law. ${ }^{4}$

The arrest and charges stemmed from a colonial era law in place prior to Kenya's independence in 1963. As with many former British colonies, Kenya inherited and retained the Colonial Office Model Code of 1930 as its own national Penal Code. Section 162 of the Penal Code classifies 'carnal knowledge of a person against the order of nature' as a felony, punishable by up to 14 years in prison. ${ }^{5}$ The law is widely acknowledged to prohibit anal sex or sexual conduct

1 COL \& Another $v$ Resident Magistrate Kwale Court \& 4 Others eKLR, Petition 51 of 2015, 16 June 2016, kenyalaw.org/caselaw/cases/view/12375/ (accessed 29 November 2018). COL and GMN were charged with (i) practising an unnatural offence contrary to sec 162(a) as read with sec 162(c) of the Penal Code (Cap 63, Laws of Kenya); (ii) committing an indecent act with an adult contrary to sec 11A of the Sexual Offences Act 3 of 2006; (iii) trafficking in obscene literature (publications) contrary to sec 181(1) of the Penal Code (Cap 63, Laws of Kenya).

2 As above.

3 The Constitution of Kenya, 2010. Petitioners claimed that the forced examination violated inter alia their right to privacy under art 22(1) and amounted to degrading treatment in violation of Kenya's obligations as a state party to the Convention Against Torture and other Cruel, Inhuman or Degrading Treatment.

$4 \quad$ As discussed in sec 4 below, this ruling was later overturned on appeal.

5 The Kenyan Penal Code, Cap 63, sec 162. 
between men, and between 2010 and 2014595 people were prosecuted under this law. 6 According to one public opinion poll, nearly 90 per cent of Kenyans find homosexuality 'unacceptable'. ${ }^{\text {' }}$

This criminalisation of consensual same-sex conduct (criminalisation) is not unique to Kenya. More than 70 countries worldwide continue to criminalise homosexuality, with more than 30 countries in Africa alone. ${ }^{8}$ To be sure, many anti-sodomy laws on the books go unenforced. Nevertheless, the presence of such laws stigmatises homosexuality by giving sexual minorities - that frequently are subjected to discrimination and physical violence - a 'criminal identity'. 9 Even if not rigorously enforced, the mere existence of anti-sodomy laws serves to express contempt and degrade the dignity of homosexual persons. ${ }^{10}$

This article examines whether the criminalisation of consensual same-sex conduct in Kenya constitutes a 'dignity taking'. This concept grows out of the ground-breaking work of Atuahene based on her extensive empirical research in South Africa. ${ }^{11}$ Atuahene defines a dignity taking as when a state 'directly or indirectly destroys or confiscates property rights from owners or occupiers and the intentional or unintentional outcome is dehumanization or infantilization'. ${ }^{12}$ While the concept was initially developed to address property rights tied to land, I build on the recent work of legal scholars and social scientists who have extended the concept to other political, legal and issue domains and, in so doing, have demonstrated the utility of dignity taking as a mode of understanding the depth and breadth of dignitary harm inflicted on individuals and communities through state takings of property. ${ }^{13}$ Employing a 'body as property'

6 J Ndiso 'Kenya awaits ruling in landmark case to legalise gay sex' Reuters 1 March 2018 https://www.reuters.com/article/us-kenya-lgbt-rights/kenya-awaits-ruling-inlandmark-case-to-legalize-gay-sex-idUSKCN1 GE069 (accessed 25 March 2018).

7 Pew Research Centre 'Global views on morality' 15 April 2014 http://www. pewglobal.org/2014/04/15/global-morality/country/kenya/ (accessed 28 March 2018).

8 P Duncan 'Gay relationships are still criminalised in 72 countries, report finds' 27 July 2017 https://www.theguardian.com/world/2017/jul/27/gay-relationshipsstill-criminalised-countries-report_(accessed 20 March 2018); see also A Carroll State-sponsored homophobia (2016).

9 Human Rights Watch This alien legacy: The origins of 'sodomy' laws in British colonialism (2008) 32. See also CR Leslie 'Creating criminals: The injuries inflicted by unenforced sodomy laws' (2000) 35 Harvard Civil Rights-Civil Liberties Law Review 103.

10 See TS Kogan 'Legislative violence against lesbians and gay men' (1994) Utah Law Review 209 and DM Kahan 'The secret ambition of deterrence' (1999) 113 Harvard Law Review 413.

11 See generally B Atuahene We want what's ours: Learning from South Africa's land restitution program (2014).

12 B Atuahene 'Dignity takings and dignity restoration: Creating a new theoretical framework for understanding involuntary property loss and the remedies required' (2016) 41 Law and Social Inquiry 817.

13 See, generally, Atuahene (n 12); B Atuahene (ed) 'Dignity takings and dignity restoration' (Symposium) (2017) 92 Chicago-Kent Law Review 715. 
framework, I argue that criminalisation does constitute a dignity taking. ${ }^{14}$ More specifically, as the Kenyan case illustrates, I find that criminalisation can give rise to both direct and indirect dignity takings. Criminalisation leads to a direct taking where it engenders forced examinations and medical tests, and indirect takings where the institutionalisation of stigma - marking sexual and gender minorities as criminal - creates an environment that legitimises the use of violence against individuals on the basis of their real or perceived sexual orientation or gender identity. ${ }^{15}$ Viewing criminalisation as a dignity taking not only helps one to understand the direct effects by which the state is empowered to violate the bodies of lesbian, gay, bisexual and transgender (LGBT) ${ }^{16}$ persons, but also the more pernicious ways in which the state uses homophobia as a political weapon that can exclude individuals from meaningfully participating as citizens in the social contract.

The article proceeds in three parts. First, I build on the body as property framework to connect the dignitary violations of criminalisation to the property law concept of dignity takings. Second, I describe the nature of criminalisation in Kenya and identify both the direct and indirect dignity takings that flow from state-sanctioned homophobia. This section relies on analyses of media reports, court documents, non-governmental organization (NGO) records, and semi-structured interviews to identify evidence of the dehumanising and infantilising effects of criminalisation. Third, I address the question of whether activists' efforts to decriminalise consensual same-sex conduct in Kenya reflect a case of dignity restoration. I draw on original fieldwork, including 23 semi-structured interviews with Kenyan LGBT activists and public officials, ${ }^{17}$ to explore the pathways through which advocates mobilise to assert their agency and dignity in challenging discriminatory laws. I find that, while this case does not yet rise to the level of dignity restoration since homosexuality remains illegal in Kenya, it does highlight how non-state actors can catalyse the process of dignity restoration where the state remains intransigent. In this case activism itself can serve the ends of dignity restoration by foregrounding the agency of activists and reclaiming autonomy and dignity through coordinated pressure campaigns that assert the humanity of sexual and gender minorities. Moreover, the

14 On the proposition of body as property, see JF Acevedo 'Dignity takings in the criminal law of seventeenth century England and the Massachusetts Bay Colony' (2017) 92 Chicago-Kent Law Review 743.

15 In the case of an 'indirect taking' the state tacitly authorises the theft of property by failing to protect the property and personhood of targeted communities.

16 Many scholars and activists adopt labels including lesbian, gay, bisexual, transgender, intersex, queer, and questioning to reflect various identities. Many activists interviewed used the acronym LGBTI, although transgender and intersex issues are not central to their advocacy efforts. For simplicity in this essay, I use the terms 'LGBT' and 'queer' to encompass sexual and gender minorities.

17 The interviewees were granted confidentiality in accordance with the requirements of institutional review board approval. 
Kenyan case illustrates how the language and institutions of international human rights law can provide an opportunity for activists to universalise and legitimise their dignity claims in the face of neo-colonial critiques against LGBT rights.

\section{Identifying the property interest in LGBT rights}

Atuahene's research on the dispossession of black South Africans under apartheid drew attention to the extraordinary nature of the taking in which the loss of property is inextricably linked to a more insidious perpetuation of dehumanising or infantilising policies and practices toward oppressed groups. ${ }^{18}$ In many ways, then, the application of dignity takings to LGBT rights reflects a natural extension of the concept to other subjugated communities. Indeed, appeals to human dignity have been central in United States (US) gay rights jurisprudence. Most notably, in his string of US Supreme Court opinions affirming the fundamental rights of gays and lesbians, ${ }^{19}$ Justice Anthony Kennedy has drawn what Tribe terms a doctrine of 'equal dignity'. In Lawrence $v$ Texas, for example, which struck down state anti-sodomy laws as a violation of the Fourteenth Amendment right to substantive due process, Justice Kennedy held that the stigma of a criminal statute against consensual same-sex conduct offends the 'dignity of persons charged'. ${ }^{20}$ The preservation of human dignity thus is integral to the claim for recognising the liberty rights of gays and lesbians. This reasoning finds its apogee in Obergefell $v$ Hodges, where Justice Kennedy, again writing for the majority, affirms the right to equal marriage for same-sex couples: ${ }^{21}$

No union is more profound than marriage, for it embodies the highest ideals of love, fidelity, devotion, sacrifice, and family. In forming a marital union, two people become something greater than once they were. As some of the petitioners in these cases demonstrate, marriage embodies a love that may endure even past death. It would misunderstand these men and women to say they disrespect the idea of marriage. Their plea is that they do respect it, respect it so deeply that they seek to find its fulfillment for themselves. Their hope is not to be condemned to live in loneliness, excluded from one of civilization's oldest institutions. They ask for equal dignity in the eyes of the law. The Constitution grants them that right.

The concept of dignity also features prominently in foreign legal discourses around LGBT rights. Dignity has been key to the South African Constitutional Court's jurisprudence advancing gay rights. In Minister of Home Affairs $v$ Fourie, the Court extended the right to marry

18 See Atuahene (n 12).

19 L Tribe 'Equal dignity: Speaking its name' (2015-2016) 129 Harvard Law Review 16; see generally Romer v Evans 517 US 620 (1996); Lawrence v Texas 539 US 558 (2003); United States $v$ Windsor 570 US 744 (2013); Obergefell v Hodges 576 US (2015).

20 Lawrence (n 19) para 575.

21 Obergefell (n 19) 28. 
to same-sex couples, finding that 'the exclusion to which same-sex couples are subjected, manifestly affects their dignity as members of society'. ${ }^{22}$ The Colombian Constitutional Court similarly appealed to human dignity in its 2011 opinion ruling that the prohibition on same-sex marriage 'violates the right of same-sex couples to constitute a family in conditions of equality and dignity' under the law. ${ }^{23}$ In other words, the concept of dignity in the analysis of LGBT rights is not new. The dignitary harm of treating sexual and gender minorities as marginalised and unequal lies at the centre of past and current debates around LGBT rights. ${ }^{24}$

However, to examine whether the criminalisation of consensual same-sex conduct constitutes a dignity taking, we must identify the property interest that connects dignity claims to the direct and indirect confiscation of property by the state. For this, I build on previous studies that identify the body as property. As early as the seventeenth century, Locke contended that every individual 'has a property in his own person: This no body has any right to but himself. $^{25}$ The right to fully control and assert ownership over one's body forms a precondition of Locke's labour theory of property. To the extent that individuals relinquish rights to political society for the protection of their property, the government is obliged to minimally infringe upon or regulate one's property interest in their own body. ${ }^{26}$

Legal scholars have further developed this framework to explore an intrinsic link between the ownership of the physical body and one's autonomous existence. Margaret Radin develops the 'personhood perspective' premised on the notion that one maintains sole ownership over one's body, and that interference with the body infringes on the right to be treated as a person. If that is the case, she argues, 'the body is quintessentially personal property because it is literally constitutive of one's personhood'. ${ }^{27}$ The property interest in the body, therefore, is 'the right to possess one's own body and the

22 Minister of Home Affairs v Fourie 2006 (1) SA 524 (CC) (SAfr) para 114, as discussed in $M$ Finck 'The role of human dignity in gay rights adjudication and legislation: A comparative perspective' (2016) 14 International Journal of Constitutional Law 39.

23 C-577 (2011) Colombia Constitutional Court.

24 Similar to Kenya, sec 377 of the Indian Penal Code, also a relic of the British colonial era law, has been employed to criminalise consensual same-sex conduct. In the 2009 case of Naz Foundation v Government of NCT of Delhi \& Others, the Delhi High Court declared the law unconstitutional as applied to the consensual private acts of adults ('The discrimination severely affects the rights and interests of homosexuals and deeply impairs their dignity' (92)). On 11 December 2013 the Indian Supreme Court overturned this ruling and upheld the constitutionality of sec 377. On 10 July 2018 the Supreme Court heard a new challenge to the law based, in part, on recent jurisprudence affirming a fundamental right to privacy. As at the date of publication, the Court had not yet issued judgment in the case. See 'India's Supreme Court considers decriminalising gay sex' New York Times 10 July 2018.

25 J Locke Second treatise of government (1980).

26 See Acevedo (n 14) 743.

27 MJ Radin 'Property and personhood' (1982) 34 Stanford Law Review 966. 
right to exclude others from it'. ${ }^{28}$ This exclusion includes the right against intrusive measures by the state. According to Ramachandran, the body is particularly personal as it grounds our subjective experiences and identities. ${ }^{29}$ Ownership over the body is necessary to buffer against coercive efforts by the state or powerful actors to consolidate control over personal subjectivity - that is, thoughts, beliefs, and values - and to defend against the suppression of alternative or queer identities. 30

Just as individuals have a property right in the body as a whole, that right extends to the body's component parts. As Rao notes, US case law treats bodily fluids, such as blood, as products that can be bought and sold on the market. ${ }^{31}$ Courts have come to see blood as 'a fullfledged commodity' produced by its owner and thus considered property. ${ }^{32}$ In Moore $v$ Regents of the University of California, the Californian Supreme Court held that the patient could not claim a property right to his spleen cells as he had given his consent and did not expect to retain possession after they had been removed from his body. ${ }^{33}$ However, the Court's finding that a property right was lost with the cells' removal implies that there was a property interest in the cells while they were still in Moore's body. ${ }^{34}$

Others have employed this framework more concretely in research on worker injuries and criminal justice. Nadas and Rathod argue that injuries suffered by immigrant workers can result in a dignity taking where lax state regulation and a climate of anti-immigrant hostility render the injuries a property right violation. ${ }^{35}$ In a study of police misconduct, Acevedo highlights the dignitary harm of discriminatory practices of the New Orleans Police Department, which targeted LGBT individuals for stops and did not adequately investigate crimes committed against LGBT persons. ${ }^{36}$ Baer similarly applies the body as property framework to his analysis of Chicago's Jon Burge police torture scandal, in which police officers regularly abused black criminal suspects to extract confessions. ${ }^{37}$

28 R Rao 'Property, privacy, and the human body' (2000) 80 Boston University Law Review 364.

29 G Ramachandran 'Against the right to bodily integrity: Of cyborgs and human rights' (2009) 87 Denver University Law Review 4.

30 Ramachandran (n 29) 39.

31 Rao (n 28) 371.

32 Rao 372, discussing Carter v Interfaith Hospital of Queens (1969) 304 NYS 2d 97, 101.

33 (1990) $51 \mathrm{Cal} 3 \mathrm{~d} 120$.

34 Acevedo (n 14) 629.

35 R Nadas \& J Rathod 'Damaged bodies, damaged lives: Immigrant worker injuries as dignity takings' (2018) 92 Chicago-Kent Law Review 1155.

36 JF Acevedo 'Restoring community dignity following police misconduct' (2015) 59 Howard Law Journal 628-629.

37 AS Baer 'Dignity restoration and the Chicago police torture reparations ordinance' (2017) 92 Chicago-Kent Law Review 769. 
To be sure, conceptualising the body as property raises difficult questions about how such property may be commodified or otherwise exchanged on the market. Some might argue that treating the body as property opens a Pandora's box of potential dignitary harms, where one opts to use her body in a manner that others consider degrading or demeaning. A full treatment of these concerns, however, is beyond the scope of this analysis. Rather, I employ this framework to the extent that it underscores a property interest in the physical body and the concomitant right to protect against dispossession or destruction of that property that can occur either through direct or indirect takings.

\section{Is criminalisation a dignity taking?}

\subsection{Direct takings through forced examinations}

For Atuahene, dignity takings are distinct from other forms of takings (for instance, constitutional takings) because, in addition to the involuntary loss of property, the 'intentional or unintentional outcome is dehumanization or infantitilization'. ${ }^{38}$ She specifies that dehumanisation is 'the failure to recognize an individual's or group's humanity', and infantilisation is 'the restriction of an individual's or group's autonomy based on the failure to recognize and respect their full capacity to reason'. ${ }^{39}$ While a case of theft by the state need not include both dimensions to constitute a dignity taking, I argue that the direct taking stemming from criminalisation, in the form of forced anal examinations and medical procedures, reflects the confiscation of property that results in both infantilisation and dehumanisation.

The involuntary loss of property is evident in the 2015 case of forced anal examinations noted above. Upon their arrest the two men accused of engaging in homosexual acts were escorted by police to the large public hospital in Mombasa. ${ }^{40}$ Prosecutors sought and received a court order that the men submit to 'medical examination'. ${ }^{41}$ The men were forced to disrobe in front of police and hospital staff. As one of the men later recounted to Human Rights Watch, '[t]hey told me to lay down and put my legs up and they just looked at it. Then they put something inside that felt like a stick. I didn't see it because I was lying down. It felt terrible, and

38 Atuahene (n 12) 817. For a more general discussion of various forms of takings, see B Atuahene 'Takings as a socio-legal concept: Interdisciplinary examination of involuntary property loss' (2016) 12 Annual Review of Law and Social Science 171.

39 Atuahene (n 12) 801.

40 Human Rights Watch 'Dignity debased: Forced anal examinations in homosexuality persecutions' (2016) 30 https://www.hrw.org/report/2016/07/12/ dignity-debased/forced-anal-examinations-homosexuality-prosecutions (accessed 26 March 2018).

$41 \quad$ COL (n 1) para 4. 
uncomfortable. $^{\prime 42}$ Blood samples were withdrawn to test for HIV and hepatitis B. Furthermore, the men claimed that they did not fully understand the nature of the examination they were about to undergo, and that they signed consent forms under duress while in police custody. ${ }^{43}$ Given the involuntary taking of bodily fluids and the manipulation of orifices in the course of the examination, one can observe a clear violation of the men's property rights over their bodies. ${ }^{44}$

In a general sense, medical personnel that have engaged in such examinations may justify their actions as facilitating a public good. The testing is not viewed as a human rights violation; rather, medical personnel are 'helping' men by 'inform[ing] them if they have [sexually transmitted infections], which allows them to get treatment'. ${ }^{45}$ Although testing and treatment for HIV and hepatitis B ostensibly are beneficial from a public health perspective, the coercive testing of men suspected of engaging in same-sex conduct suggests that they are unable to act responsibly on their own behalf - that they would not otherwise seek out testing or treatment. Indeed, methods of forced examinations are not regularly employed against other populations with a high incidence of HIV or used for recognised clinical purposes. ${ }^{46}$ Such treatment infantilises men by perpetuating the notion that they lack the capacity to monitor their own sexual health.

On 16 June 2016 Justice Anyara Emukule of the Mombasa High Court ruled that the examination was lawful and did not violate the petitioners' constitutional rights. While the judgment dealt a blow to LGBT activists, who saw it as a dangerous precedent, the text of the ruling itself offers a compounding injury through its infantilisation of men who engage in same-sex sexual conduct. In his ruling, Justice Emukule concludes: ${ }^{47}$

I am not a doctor, nor do I understand much biology. But this much I could be tested on. The human alimentary canal starts from the mouth, ringed with lips, teeth, tongue and salivary glands, leading to the throat, the small intestine, large intestine the digestive system where the necessary bodily nutrients are squeezed and absorbed into the body and surplus waste is passed out through the urinary duct, for waste water and the rectum

42 Human Rights Watch (n 40) 30.

43 Human Rights Watch 'Kenya: Court upholds forced anal exams' 16 June 2016 https://www.hrw.org/news/2016/06/16/kenya-court-upholds-forced-anal-exams (accessed 4 April 2018).

44 The prosecution argued that, in the absence of explicit consent from the accused, it nevertheless had the authority to seek a court-ordered examination according to sec 36(1) of the Sexual Offences Act, which allows for sample collection for the purpose of gathering evidence.

45 Human Rights Watch (n 40) 2.

46 C Cichowitz et al 'Forced anal examinations to ascertain sexual orientation and sexual behaviour: An abusive and medically unsound practice' (2018) 15 PLoS Med http://journals.plos.org/plosmedicine/article?id=10.1371/journal.pmed.100 2536 (accessed 10 April 2018).

$47 \mathrm{COL}$ (n 1) paras 46-47. 
through the anus for the solid waste. That to my understanding means that neither the mouth nor the anus is a sexual organ. However, if modern man and woman have discovered that these orifices may be employed or substituted for sexual organs, then medical science or the purveyors of this new knowledge will have to discover or invent new methods of accessing those other parts of the human body even if not for purposes of medical forensic evidence, but also curative medical examination.

Although he concedes his limited medical knowledge, the judge focuses on the anatomical and physiological aspects of same-sex conduct and its relationship to the medical examination. He provides a level of detail and specificity that underscores his association of homosexual conduct with digestive processes. The implication of this condescending remark is that engaging in consensual same-sex behaviour does not align with his understanding of appropriate sexual behaviour. He operates from the premise that anal sex is not a practice that one could or would engage in for sexual fulfilment. His failure to even consider the substantive question of whether the examination, given its putative necessity for gathering evidence, violated the petitioners' constitutional rights, reinforces the infantilisation of the men, as the judge instead opts to consider only their relationship to their own bodies and private acts.

At the same time, his detailed focus on biological processes and opprobrium toward homosexual acts signals a broader dehumanisation of men who engage in consensual same-sex conduct. In From disgust to humanity, Nussbaum examines how the politics around homosexuality are rooted in a rhetoric of disgust. ${ }^{48}$ Opponents characterise homosexual behaviour as 'dirty' and 'revolting', focusing on bodily fluids and 'aspects of the body that many if not most people view with discomfort'. ${ }^{49}$ They also reduce anal sex to the pathologised bodies of gay men with the goal, according to Nussbaum, of '[inspiring] simple revulsion and loathing for gay men, and to link their practices to disease and danger'.50 Justice Emukule's ruling reflects a similar language of disgust, strictly associating anal sex with bodily waste. To be sure, the comparison and rhetoric alone do not rise to the level of dehumanisation. However, when viewed in conjunction with Justice Emukule's ratification of the invasive forced medical examinations and testing, the full effect is 'an insult to human dignity reminiscent of prisons and concentration camps, where the removal of simple bodily privacy became a way of marking some people as not fully human'. ${ }^{51}$ In so doing, the judge reduces the petitioners to a status less than human, whose 'disgusting' practices render them subject to invasive procedures and violations of their bodily integrity and property rights.

48 See MC Nussbaum From disgust to humanity: sexual orientation and constitutional law (2010).

49 Nussbaum (n 48) 5.

50 As above.

51 Nussbaum (n 48) 55. 


\subsection{Indirect takings through state-sanctioned violence}

A second taking arises from the hostile, homophobic environment enacted by the institutionalisation of anti-LGBT stigma and the criminalisation of sexual and gender minorities in Kenya. An indirect taking can stem from state inaction where the state has a duty to act. ${ }^{52}$ Among the most fundamental responsibilities of the state, for which individuals accede to the social contract, is security. Political philosophers from John Locke to Jean-Jacques Rousseau have recognised the obligation of government to protect natural rights, including the self-preservation and physical integrity of its citizens. 53 Not only does the Kenyan government in many instances fail to protect the safety of its most vulnerable citizens, but by criminalising same-sex sexual conduct - and therefore the identities of LGBT Kenyans - it creates a climate that condones violence against individuals on the basis of their real or imputed sexual orientation or gender identity and subordinates them to the dominant orientations and expressions of gender and sexuality. In this sense it is not merely a metaphorical social contract from which LGBT Kenyans are marginalised; rather, anti-sodomy laws target the very essence of sexual and gender minorities and render them subhuman through violent exclusion. They are empirically restricted from full citizenship because the structures of power within that very contract a priori exclude them for who they are and deny them the dignity of full participation in the polity. ${ }^{54}$

\subsubsection{A dehumanising climate for sexual and gender minorities}

Kenyans who identify as or are perceived to be LGBT persons face a dangerous national climate. While criminalisation originated with the colonial era penal code, Kenyan political and religious figures have subsequently championed criminalisation as an anti-colonial-rallying cry and have used the persecution of homosexuality as a domestic scapegoat for external political and economic pressure. In 1999 then President Daniel arap Moi publicly condemned homosexuality as a colonial export: 'It is not right that a man should go with another man or woman with another woman,' he railed. 'It is against African tradition and Biblical teaching. I will not shy away from warning

52 Atuahene (n 11) 27.

53 Locke (n 25); JJ Rousseau The social contract: Or, the principles of political rights (1893).

54 This argument builds on the work of Mills, who uses the concept of 'The racial contract' to describe 'a rhetorical trope and theoretical method for understanding the inner logic of racial domination and how it structures the polities of the west and elsewhere' relative to the central concept of Western political philosophy the social contract. He describes how a racialised social contract employs law and custom to subordinate non-whites to an overriding structure of white supremacy. See CW Mills The racial contract (1997) 6. I thank John Acevedo for highlighting this comparison. 
Kenyans about the dangers of the scourge [of homosexuality]. ${ }^{55}$ His remarks followed events in neighbouring Uganda, where a few days earlier President Yoweri Museveni had ordered the police to 'look for homosexuals, lock them up and charge them' after a same-sex wedding had been held outside Kampala. 56 Moi's attack likely was in response to criticism by the Roman Catholic Church, which had recently criticised the President for, among other crimes, fomenting political violence and rampant corruption. ${ }^{57}$

Although Kenyans ratified a progressive, rights-rich Constitution in 2010, the interests of LGBT individuals were excluded from the reform process. The previous Constitution had long been deemed ineffective and insufficiently protective of fundamental rights. ${ }^{58}$ The Constitution of Kenya Review Commission was established in 2000 to propose and evaluate constitutional reforms that would strengthen fundamental rights and institutions to promote them. The review offered an opportunity to expand the discussion around conceptions of equality and non-discrimination to include protections for sexual orientation and gender identity. Rather than encompassing the diverse rights and interests of marginalised groups, the constitutional referendum campaign proved to be a crucible for mobilising homophobia.

In October 2010 the issue of LGBT rights was thrust into the spotlight following the civil partnership of two Kenyan citizens, Charles Ngengi and Daniel Gichia, in London. ${ }^{59}$ The local press sensationalised what was seen as the first such ceremony between two Kenyans. In response, the Committee of Experts on Constitutional Review publicly rebuffed the explicit inclusion of 'homosexual and lesbians' rights' in the draft Constitution, viewing them as a poison pill that would lead voters to reject the proposed Constitution. ${ }^{60}$ Nevertheless, opponents of the new Constitution seized on the issue of LGBT rights during the referendum campaign, charging that it would legalise same-sex marriage as a strategy of mobilising

55 'Moi condemns gays' BBC 30 September 1999 http://news.bbc.co.uk/2/hi/africa/ 461626.stm (accessed 15 March 2018).

56 C McGreal 'Debt? War? Gays are the real evil, say African leaders' The Guardian 1 October 1999 https://www.theguardian.com/world/1999/oct/02/chrismcgreal (accessed 4 April 2018).

57 As above. See also KG Adar \& IM Munyae 'Human rights abuse in Kenya under Daniel arap Moi, 1978-2001' (2001) 5 African Studies Quarterly 1.

58 CE Finerty 'Being gay in Kenya: The implications of Kenya's new Constitution for its anti-sodomy laws' (2013) 45 Cornell International Law Journal 447.

59 M Ringa 'Law review experts rule out rights for homosexuals' Daily Nation 18 October 2009 https://www.nation.co.ke/news/1056-674074-jkp312z/index.html (accessed 4 April 2018).

60 As above. See also The Equal Rights Trust, 'ERT interview with David Kuria, Chairman of the Gay and Lesbian Coalition of Kenya (GALCK)' (2010) 5 The Equal Rights Review 86-87. 
opposition. During a 'No' campaign rally, MP Linah Jebii Kilimo cautioned: 61

We can see now that they are saying that should this PCK [Proposed Constitution of Kenya] pass it will not discriminate against any marginalised groups that include sex. You have heard it said that there are gay marriages; there is lesbianism, isn't it? And we know that according to our African culture ... we don't even want to mention ... but now it looks like they will be protected under the PCK. They will have rights. That means we are introducing gay marriages in our Constitution, we are allowing lesbianism in our Constitution.

The campaign ultimately was ineffective, and the new Constitution was approved in 2010. Yet, Prime Minister Raila Odinga reassured the public that homosexuality would not be sanctioned under the new constitutional order: ${ }^{62}$

We will not tolerate such behaviours in the country. The Constitution is very clear on this issue and men or women found engaging in homosexuality will not be spared. Any man found engaging in sexual activities with another man should be arrested. Even women found engaging in sexual activities will be arrested. This [homosexual] kind of behaviours will not be tolerated in this country. Men or women found engaging in those acts deserve to be arrested and will be arrested.

This sentiment presaged a continued anti-gay climate. As recently as in August 2014, an 'Anti-Homosexuality Bill' was introduced in the Kenyan Parliament that would have prohibited 'any form of sexual relations between persons of the same sex', as well as the 'promotion' of such practices in public institutions, mandating life imprisonment for an individual that 'aids, abets, counsels or procures another to engage in acts of homosexuality ...'63

On the one hand, we can understand this propagation of homophobia as part of a global pattern of state and nation building, where an 'LGBT boogeyman' serves as a focal point for deflecting international and/or domestic political pressure. ${ }^{64}$ As Kenya underwent a constitutional revision, which encompassed a process of defining legal citizenship, the politics of organising citizenship turned, at least in part, on competing claims about sexuality and gender roles. Such rhetorical violence degrades and marginalises LGBT Kenyans, but does it rise to the level of a dignity taking? There are multiple forms of

61 Kenya Human Rights Commission 'Wanjiku's journey: Tracing Kenya's question for a new Constitution and reporting on the 2010 national referendum' (November 2010) 25 http://www.khrc.or.ke/publications/38-wanjiku-s-journey-tracing-kenyas-quest-for-a-new-constitution-reporting-on-the-2010-referendum/file.html (accessed 31 March 2018).

62 B Momanyi 'Arrest gays, Kenyan PM orders' Capital News 28 November 2010 https://www.capitalfm.co.ke/news/2010/11/arrest-gays-kenyan-pm-orders/ (accessed 31 March 2018).

63 C Wafula 'Draft Bill proposes harsh penalities against gays' Daily Nation 9 August 2014 http://www.nation.co.ke/news/politics/Republican-Liberty-Party-Bill-Homo sexuality/-/1064/2414002/-/jiv3s4z/-/index.html (accessed 31 March 2018).

64 M Bosia 'Why states act: Homophobia and crisis' in M Weiss \& M Bosia (eds) Global homophobia: States, movements, and the politics of oppression (2013) 37. 
violence that do not necessarily threaten the physical body. However egregious the acts, hate speech or public shaming, for example, do not rise to the level of a dignity taking if there is no destruction of the body or other taking of property. ${ }^{65}$ On the other hand, I argue that there is a dignity taking where criminalisation and anti-gay stigma engender physical violence due to state inaction - that is, where the state neither recognises nor protects its vulnerable queer population, which is dehumanised through rhetorical and physical exclusion from full participation in the social contract.

LGBT Kenyans have faced persistent physical violence and death threats. In a seminal report from 2011, the Kenya Human Rights Commission (KHRC), an $\mathrm{NGO}^{66}$ documented instances of violence against the LGBT community. 'The outlawed amongst us' was the first comprehensive, nationwide effort to investigate the situation of sexual and gender minorities in Kenya, based on more than 450 interviews. $^{67}$ Respondents reported physical violence including harassment, rioting, beatings, lynching, and mob justice. ${ }^{68}$ Individuals recalled being forcibly removed from nightclubs and public spaces. ${ }^{69}$ Several related accounts of being gang raped: ${ }^{70}$

Earlier this year in February, we had come home late with two of my gay friends (all from our estate) from town. It was deserted. When we alighted of the matatu, we found some four men on the stage. They ordered us to stop and said they knew us and that we were shogas [homosexuals]. They said they were mungiki. They slapped us and demanded silence as they dragged us to a bush. We were forced to bend and undress and they raped us using saliva as lubricant. They never used any condom. They strangled any who moaned of pain. When they were done, they beat us up and let us go, threatening to kill us if we ever reported or told anyone.

I documented similar accounts through personal interviews with activists in 2013 and 2014. One activist recounted being raped by a group of local men intent on 'correcting' her orientation through sexual violence. 71 Another described the danger faced in daily interactions with family and neighbours: ${ }^{72}$

65 Acevedo (n 14) 767 (noting that 'punishments such as the imposition of "scarlet letters" and other shaming punishments (sitting on the gallows, wearing hemp ropes) were humiliating, but did not rise to the level of dignity takings.)

66 The KHRC is distinct from the quasi-governmental Kenya National Human Rights Commission established by art 59 of the 2010 Constitution of Kenya.

67 Kenya Human Rights Commission 'The outlawed amongst us: A study of the LGBTI community's search for equality and non-discrimination in Kenya' (2011) http://www.khrc.or.ke/mobile-publications/equality-and-anti-discrimination/70the-outlawed-amongst-us/file.html (accessed 15 March 2018).

68 Kenya Human Rights Commission (n 67) 27.

69 Kenya Human Rights Commission 28.

70 Kenya Human Rights Commission 29. The Mungiki are a Kikuyu religio-political movement, which traces its militancy to the anti-colonial Mau Mau rebellion and has some elements linked to sectarian political violence. See PW Kagwanja 'Facing Mount Kenya or facing Mecca: The Mungiki, ethnic violence and the politics of the Moi succession in Kenya, 1987-2002' (2003) 102 African Affairs 25.

71 Personal Interview with Kenyan LGBT activist (B) on 5 September 2014.

72 Personal interview with Kenyan LGBT activist (E) on 27 August 2014. 
My neighbours - I played with their kids. One day I went to work. I came back, and my neighbours would not speak to me. The next day I was attacked. When this happened, seven guys waited for me outside my gate ... When I walked past, they started pushing me and kicking me. My neighbour and everybody else did nothing. I was lucky because I escaped. I cannot just go and say to people I'm gay, or lesbian, or homosexual, because they want to kill me.

What is more, there is little accountability for those perpetrating such acts of violence. As one activist remarked, '[t]he police do nothing. They are not interested in us. ${ }^{.73}$ Although there are existing laws that proscribe physical violence, including assault and rape, state officials 'indiscriminately apply and enforce existing laws to protect and safeguard the rights of [LGBT] persons'. ${ }^{74}$ As a result, impunity is the norm, and LGBT Kenyans, often afraid to go to the police, are further dehumanised because the state fails to recognise them as worthy of protection and the pursuit of justice on their behalf.

The criminalisation of consensual same-sex conduct, and the resulting criminalisation of queer identities, enable a climate that condones physical violence against individuals on the basis of their actual or perceived sexual orientation or gender identity. Some might argue that this is more consistent with a case of radical 'othering' that does not constitute a dignity taking per se. ${ }^{75}$ Indeed, Atuahene has cautioned against the overextension of the dignity taking concept that would diminish its analytic utility. ${ }^{76}$ However, I contend that the violation of bodily integrity fuelled by a context of dehumanisation in which LGBT Kenyans are defined as un-African, un-Kenyan, and not worthy of full participation in the political life of the country, denies these individuals their full humanity and sets them apart from the social contract, thereby restricting their capacity to engage as equal citizens. In other words, homophobic violence against the property and personhood of LGBT Kenyans is the logical extension, and physical manifestation, of a politic that seeks to deny the place of LGBT Kenyans in the social contract and thus deny them their dignity.

\section{Decriminalisation as dignity restoration?}

Efforts to decriminalise consensual same-sex conduct in Kenya have been met with limited success. On 22 March 2018 the Court of Appeal at Mombasa declared forced anal examinations unconstitutional, overturning the previous ruling from 2015 that

Personal interview with Kenyan LGBT activist (A) on 4 September 2014.

Kenya Human Rights Commission (n 67) 31.

See A Kedar 'Dignity takings and dispossession in Israel' (2016) 41 Law and Social Inquiry 866.

76 Atuahene (n 12) 809. 
upheld the legality of such procedures. ${ }^{77}$ However, as demonstrated by the persistent use of homophobic rhetoric and queer scapegoating by political elites, the Kenyan government has demonstrated little willingness to fully acknowledge or remedy the dignity takings against LGBT people that are enacted through criminalisation. The concept of dignity restoration entails a 'remedy that seeks to provide dispossessed individuals and communities with material compensation through processes that affirm their humanity and reinforce their agency ${ }^{\prime 78}$ At its core, this model of dignity restoration emphasises the process through which those who are the subjects of dignity takings seek redress and 'are made whole'. ${ }^{79}$ To the extent that criminalisation remains a part of the Kenyan Penal Code and victims have not been compensated, this does not represent a case of complete dignity restoration as Atuahene defines it. Yet, the concept serves to draw our attention to the agency of local activists as well as the broader mobilisation dynamics through which LGBT Kenyans are advocating decriminalisation as a mode of dignity restoration. In addition, the Kenyan case illuminates the use of human rights framings and mechanisms to contest homophobia where other domestic institutions prove closed or unresponsive to dignity claims. ${ }^{80}$

The application of international human rights to sexual orientation and gender identity does not signal the pursuit of new or special categories of rights. Rather, the architecture of rulings by international institutions and 'soft law' norms regarding sexual orientation and gender identity reflects an extension of existing universal and fundamental rights to life and equality. 81 In the face of domestic opposition, Kenyan activists have drawn upon international human

77 T Odula 'Kenyan court rules forced anal exams as gay test unlawful' Washington Post 22 March 2018; COI \& Another v Chief Magistrate Ukundla Law Courts \& 4 Others [2018] eKLR, Civil Appeal 56 of 2016, kenyalaw.org/caselaw/cases/view/ $150781 /$ (accessed 29 November 2018).

78 Atuahene (n 12) 819.

79 As above.

80 Human rights offer one of many possible modes of asserting dignity claims. Rights are entitlements owed to individuals by virtue of being human. A number of international human rights treaties expressly link human rights to dignity, that is, rights derive from the inherent dignity of each person. How human rights are applied or utilised to realise human dignity can vary across political and cultural contexts. See J Donnelly 'Human rights and human dignity: An analytic critique of non-Western conceptions of human rights' (1982) 76 American Political Science Review 303.

81 At the international level, the application of human rights principles to sexual orientation and gender identity has occurred across a range of organisational forums and institutions. In 2006 a group of eminent international lawyers and human rights experts outlined a set of existing universal human rights obligations that applied to sexual orientation and gender identity (see https:// yogyakartaprinciples.org/). A number of UN bodies have applied human rights law to cases implicating diverse sexual orientations and gender identities, including the Human Rights Committee, the Committee on Economic, Social, and Cultural Rights, and the Committee on the Rights of the Child. See M O'Flaherty $\&$ J Fisher 'Sexual orientation, gender identity and international human rights law: 
rights norms to push for equal protection under the law. ${ }^{82}$ Two developments made it appealing for activists to adopt explicit human rights framings for LGBT advocacy. First, the 2010 Constitution established a national human rights institution, the Kenya National Commission on Human Rights (KNCHR), whose operations are guided by international human rights laws and principles. ${ }^{83}$ As an independent body, the KNCHR has an agenda-setting power distinct from the core branches of government. The LGBT community developed an early relationship with the KNCHR and felt it could provide a forum for institutionalising sexual and gender minority rights within mainstream domestic human rights discourse. ${ }^{84}$ Second, the Kenyan Constitution incorporates international law directly into domestic law. It creates an affirmative obligation on the state to 'enact and implement legislation to fulfil its international obligations in respect of human rights and fundamental freedoms'. ${ }^{85}$ International human rights norms became explicitly applicable to domestic legal and political debates, and LGBT activists anticipated opportunities at the regional and international level to pressure the government to enact pro-LGBT reforms.

In May 2010 activists initiated efforts to increase LGBT visibility through public acts of human rights claiming. As one activist told me, ' $[\mathrm{t}]$ he constitutional review process opened a national dialogue around human rights that we thought we could build on' ${ }^{86}$ The Gay and Lesbian Coalition of Kenya (GALCK) - an umbrella organisation for groups working on behalf of LGBT rights - partnered with the Kenyan Human Rights Commission to produce a public celebration for the International Day Against Homophobia. The event was held at the National Museum of Kenya, and media outlets were invited to cover the event for the first time. Lawrence Mute, at the time a commissioner on the KNCHR, spoke at the event in support of LGBT rights. ${ }^{87}$ That same year GALCK organised events around World AIDS Day, drawing attention to the link between homophobia and the spread of HIV in Kenya. ${ }^{88}$ A Human Rights Day celebration in

Contextualising the Yogyakarta Principles' (2008) 8 Human Rights Law Review 207. In 2016 the UN Human Rights Council called for an independent expert on protection against violence and discrimination based on sexual orientation and gender identity.

82 This discussion of LGBT advocacy in Kenya is based upon fieldwork conducted in 2013 and 2014. These events were previously discussed in AM Shaw 'Claiming international rights: Tactical forms of human rights mobilisation in Colombia and Kenya' unpublished PhD thesis, Northwestern University, 2015 ch 4.

83 The KNCHR operates in accord with the UN Paris Principles; see Office of the High Commissioner for Human Rights 'Principles relating to the Status of National Institutions (The Paris Principles)' UN GAOR 48/134 of 20 December 1993.

84 Personal interview with Kenyan human rights activist (E) 27 August 2014.

85 Kenya Constitution Ch IV sec 21(4).

86 Personal interview with Kenyan LGBT activist (B) on 5 September 2014.

87 L Barasa \& J Wanja 'LGBT celebrate IDAHO, go public' Daily Nation 20 May 2010.

88 UHAI-EASHRI Lived realities, imagined futures: Baseline study on LGBTI organising in Kenya 16-17. 
collaboration with KHRC and KNCHR included participation by Makau Mutua and Martha Karua, an eminent legal scholar and former Minister of Justice, respectively.

LGBT activists raised their public profile by organising events and contesting the marginalisation of and violence against sexual minorities in Kenya as human rights violations. In doing so, they attracted new elite allies who began to include LGBT activists in mainstream human rights processes. In 2010 GALCK was invited to participate in the Universal Periodic Review (UPR) of Kenya's human rights record before the United Nations (UN) Human Rights Council the periodic review process of all UN member states by the Human Rights Council. KNCHR was coordinating the Kenyan government's official report. In this capacity it conducted consultative meetings with a number of civil society organisations. Lawrence Mute included GALCK in the review process to represent LGBT concerns in the UPR stakeholder report. For the first time before the Human Rights Council, the Kenyan government was compelled to address questions by other member states about discriminatory practices as regards the criminalisation of consensual same-sex behaviour. The UPR outcome report includes the Human Rights Council's recommendation that Kenya ensure equal protection for sexual minorities by decriminalising homosexual conduct. 89

A persistent charge that dehumanises LGBT Kenyans is the claim that homosexuality is 'un-African'. For activists to repudiate this and reclaim their identities as fully African and full participants in the social contract, they have pursued a strategy of constructing and disseminating an alternative narrative. The African Commission on Human and Peoples' Rights (African Commission), in part created as a counterweight to Western human rights instruments, offered an opportunity 'to create an African conversation about gay rights' ${ }^{90}$ Civil society groups in Kenya and across the region have taken a cautious approach to utilising the regional human rights system. The African Commission is historically underfunded and understaffed. The review processes are often lengthy and conducted in private, away from public scrutiny, and commissioners often lack independence from their national governments. ${ }^{91}$ As such, activists needed to ensure

89 UN Human Rights Council, 15th Session, Report of the Working Group on the Universal Periodic Review: Kenya (A/HRC/15/8), 17 June 2010 103.5.

90 Personal interview with Kenyan LGBT activist (A) on 4 September 2014; see also AM Ibrahim 'LGBT rights in Africa and the discursive role of international human rights law' (2015) 15 African Human Rights Law Journal 263. Based on my conversation with Kenyan activists, I understand an 'African conversation' around LGBT rights to reflect grassroots advocacy centred in African domestic and/or regional institutions that is led by local activists rather than relying on Western advocacy networks or external international pressure to shape domestic policies and practices around LGBT rights.

91 R Murray \& F Viljoen 'Towards non-discrimination on the basis of sexual orientation: The normative basis and procedural possibilities before the African Commission on Human and Peoples' Rights and the African Union' (2007) 29 Human Rights Quarterly 106. 
that there was an adequate opening for mobilisation prior to investing in a formal advocacy strategy at the regional level. ${ }^{92}$

In May 2006 the International Gay and Lesbian Human Rights Commission (IGLHRC), a New York-based NGO, ${ }^{93}$ along with the South Africa-based Coalition of African Lesbians (CAL), Behind the Mask, and the All-Africa Rights Initiative (AARI), organised a meeting of NGOs to coincide with the 39th session of the African Commission in Banjul, The Gambia. The Commission was reviewing Cameroon's country report, and the coalition took advantage of the opportunity to submit a shadow report on the status of LGBT people in Cameroon. ${ }^{94}$ At the 40th session in November 2006, LGBT organisations again met in Banjul, where Uganda's country report was under review. Representatives from GALCK joined activists from IGLHRC, CAL and Sexual Minorities of Uganda (SMUG) in submitting a shadow report on the status of LGBT rights in Uganda.

Kenyan LGBT activists joined representatives from regional and international NGOs at subsequent sessions of the African Commission. Activists used the NGO forum, which ran in conjunction with the official session of the Commission, to build networks and coordinate advocacy strategies. ${ }^{95}$ Lacking formal 'observer status' before the African Commission, LGBT groups were unable to directly participate in the country reviews. Instead, they were forced to file shadow reports and channel questions for commissioners through sympathetic civil society organisations that held observer status. ${ }^{96}$ By the time of the 43rd session in May 2008, nearly one-third of the participants in the NGO forum were LGBT activists. ${ }^{97}$

In an effort to play a more active role in the proceedings of the African Commission, the CAL, with participation by Kenyan activists, applied for observer status in 2008. Kenyan activists were especially interested in supporting CAL: ${ }^{98}$

The CAL was a pan-African network. We were in a position to shelter ourselves from direct harm by using a South African-based group as a legal entity and the South African network. At that time at the African Commission, most people were heavily lobbying the commissioners. So, you would have people from all over Africa teaching and strategizing. You would also have people analyzing how else to initiate conversations within the civil society space. CAL would also be able to give statements, pointing to issues and making recommendations for action.

In other words, the association with CAL not only advanced tactical goals in terms of mobilisation at the regional level, but also made

92 S Ndashe 'Seeking the protection of LGBTI rights at the African Commission on Human and Peoples' Rights' (2011) 15 Feminist Africa Legal Voice 17.

93 IGLHRC is now known as Outright Action International.

94 Ndashe (n 92) 18.

95 Personal interview with Kenyan LGBT activist (B) on 5 September 2014.

96 Ndashe (n 92) 18.

97 Ndashe (n 92) 19.

98 Personal interview with Kenyan LGBT activist (B) on 5 September 2014. 
manifest the 'African-ness' of Kenyans' claims through the inclusion of Kenyan LGBT activists as part of an expressly pan-African identity movement. When the issue finally came before the African Commission for consideration, Uganda led a number of states in opposing the CAL application on the grounds that sexual orientation and gender identity were not protected by the African Charter on Human and Peoples' Rights (African Charter). The application was deferred for further discussion and, in October 2010, CAL received official notification that the Commission had refused to grant it observer status.

The rejection of CAL's application was initially seen as a limitation on both institutional access and on the overall visibility of LGBT issues at the African Commission and across the region. It was important for activists to have an organisational presence that was explicitly LGBT in name and in substance. ${ }^{99}$ However, the rejection ultimately had a galvanising effect on CAL and LGBT advocacy at the African Commission. One activist recalled: ${ }^{100}$

When the registration was rejected, we went out in full. We had a panel at
the NGO session, but what we wanted was for people to see that we had
never been given formal reasons for rejection. We had been discriminated
against because the word 'lesbian' was in the statement. And the
Commission was taking a stand simply by refusing to comment on the
issues. So this put pressure on us, and we had to return the pressure to [the
Commission]. All levels - international, local, regional. We put together
reports, got people from all over to share their experiences. We began
advocacy at each session, met one on one with the commissioners,
developed a plan of who is the most hostile, who is most friendly.

Activists tried to court individual commissioners who they felt would be open to persuasion. Activists frequently spent time with commissioners simply trying to 'humanise' homosexuality and the violence of the lived experiences of LGBT persons in Africa. As one activist recalled, '[w]e had to show them we are people just like them, worthy of respect and security'. ${ }^{101}$ At the same time they also worked to reframe LGBT rights for other participants in the NGO forum as a matter of human rights rather than morality. Many participants from across the continent held anti-gay views that prevented LGBT issues from holding a more prominent place on the NGO Forum agenda and from receiving its full support before the African Commission. By highlighting the violence and daily struggles of LGBT individuals, activists worked to recast the debate in terms of the fundamental right to life and dignity, free from violence and insecurity, and to separate LGBT issues from debates about religious or moral approval.

In 2014, during its 55th ordinary session, the African Commission adopted Resolution 275 on the 'Protection Against Violence and

99 Personal interview with Kenyan LGBT activist (A) on 4 September 2014.

100 Personal interview with Kenyan LGBT activist (B) on 5 September 2014.

101 Personal interview with LGBT specialist at international human rights organisation on 27 August 2014. 
Other Human Rights Violations Against Persons on the Basis of Their Real or Imputed Sexual Orientation or Gender Identity'. ${ }^{102}$ The Resolution was an important step in realising full equality for LGBT persons. ${ }^{103}$ In 2013 Lawrence Mute, the Kenyan human rights expert, was appointed to the African Commission and was instrumental in shepherding the Resolution to a vote. ${ }^{104}$ The Resolution condemns violence on the bases of sexual orientation or gender identity and calls on states to ensure that appropriate measures are in place to protect victims and punish perpetrators. However, it stops short of calling for specific legal changes, such as decriminalisation or the expansion of same-sex partner rights.

While the human rights 'turn' has not yet led to decriminalisation, the modest gains achieved by activists nonetheless reflect a bottomup process of rights claiming that centres their agency in restoring their own dignity. This ongoing process has advanced the dialogue around LGBT rights in Kenya and reaffirmed the dignity of sexual and gender minorities as fully African and entitled to the same fundamental rights as their fellow citizens. This continues to be evidenced by the incremental gains of local activists through strategic litigation. In 2015 the High Court in Nairobi struck down a ruling by the Kenya Non-Governmental Organisations Coordination Board which had refused to grant official NGO status to the National Gay and Lesbian Human Rights Commission (NGLHRC) and its founder Eric Gitari, arguing that the proposed organisation promoted illegal homosexual behaviour. The Court held that the ruling violated Gitari's 'constitutionally guaranteed freedom to associate', having declared that the Constitution's protection of 'every person' extended to 'all persons living within the republic of Kenya despite their sexual orientation'. 105 In its judgment the Court drew extensively on international law, including jurisprudence of the African Commission. In March 2018 the Kenyan High Court announced that it would finally rule on a case from 2016 challenging the constitutionality of sections of the Penal Code criminalising homosexuality. ${ }^{106}$ This challenge was also spearheaded by Gitari, who makes the direct claim that such laws violate constitutional protections, including the provision that '[e]very person has inherent dignity and the right to have that dignity

102 African Commission on Human and Peoples' Rights, 55th ordinary session, 'Resolution on Protection against Violence and other Human Rights Violations against Persons on the Basis of their Real or Imputed Sexual Orientation or Gender Identity' (2014), http://www.achpr.org/sessions/55th/resolutions/275/?prn=1 (accessed 6 April 2018).

103 T Senzee 'African Commission on Human Rights passes LGBT resolution' Advocate.com 2 June 2014 https://www.advocate.com/world/2014/06/02/africancommission-human-rights-passes-lgbt-resolution (accessed 6 April 2018).

104 Personal interview with Kenyan human rights public official on 24 September 2014.

105 Petition 440 of 2013 (http://kenyalaw.org/caselaw/cases/view/108412/).

106 Ndiso (n 6); see also petition 150 of 2016. 
respected and protected'. ${ }^{107}$ At the time of the publication of this article there has not yet been a final verdict. Consensual same-sex conduct remains criminalised in Kenya.

Although falling short of decriminalisation and material compensation at this point in time, LGBT activists nonetheless have carved a path that is dignity-restorative. The very pursuit of public, grassroots activism is an assertion of agency in the face of institutionalised stigma and systemic violence. Moreover, advocacy within the regional human rights system has allowed activists to reframe LBGT rights in terms of fundamental rights to life and dignity guaranteed to all Africans, effectively countering the false claim that homosexuality is 'un-African'. As such, it is LGBT Kenyans and their allies that are driving the fight for equal dignity and full citizenship, with recent court victories reflecting a growing political and legal power, even if not a full remedy for the injustice of dignity takings.

\section{Conclusion}

The concept of dignity takings offers a powerful lens through which to examine the impact of criminalising homosexuality. In addition to the direct takings through forced medical examinations that flow from state enforcement of the Penal Code, the concept elucidates the pernicious effects of criminalisation through state inaction and the failure to protect the bodies of LGBT persons. It is often noted that anti-sodomy laws are rarely enforced where they remain official law. However, as the Kenyan case illustrates, the criminalisation of samesex conduct and, in turn, the criminalisation of LGBT identities institutionalise stigma that enables violence with the effect of dehumanising and infantilising sexual and gender minorities.

As such, any remedy necessarily requires a repeal of homophobic laws. Yet, while a favourable ruling on the constitutionality of criminalising same-sex conduct would go far in righting past wrongs, the decriminalisation of homosexuality alone would not be sufficient to constitute full dignity restoration. Dignity restoration requires an affirmative move by the state to acknowledge past injuries. A judicial ruling that overturns anti-sodomy laws would be reactive to litigants' claims and not an affirmative move by the state that takes stock of the violence - both physical and structural - that it has perpetrated against LGBT Kenyans. Activists have advanced a process that may ratify their dignity claims through judicial ruling, but the concept, as Atuahene defines it, suggests a more active and intentional response from the state. Nevertheless, the dignity restoration framework elevates the importance of activist-led mobilisation and how activism itself can serve the ends of restoring human dignity.

107 Art 28 Constitution of Kenya. 